\title{
Membangun Karakter Religius Siswa Melalui Pembelajaran Matematika
}

\author{
Khoirun Nisak \\ Jurusan Tadris Matematika, Institut Agama Islam Negeri (IAIN) Tulungagung \\ Jl. Mayor Sujadi Timur No. 46 Tulungagung \\ e-mail:nisak0697@gmail.com
}

\begin{abstract}
ABSTRAK
Matematika adalah salah satu mata pelajaran yang ada mulai dari tingkat dasar hingga tingkat tinggi. Di dalam matematika banyak sekali terkandung nilai-nilai islami, tetapi tak banyak guru yang mengetahui hal itu dan tidak banyak yang mengimplementasikannya melalui pembelajaran matematika. Pembelajaran matematika sendiri diartikan sebagai proses pemberian pengalaman belajar kepada siswa melalui serangkaian kegiatan pembelajaran. Dalam pembelajaran matematika seorang guru dapat membangun karakter religius dari seorang siswa guna membentuk insan yang islami dengan menyisipkan nilai-nilai islami. Karakter religius sangatlah dibutuhkan oleh siswa dalam menghadapi perubahan zaman dan degradasi moral, siswa diharapkan mampu memiliki dan berperilaku dengan ukuran baik dan buruk sesuai dengan ketentuan dan ketetapan yang berlaku. Bukan hanya melaui pendidikan agama, akan tetapi melalui pembelajaran matematika islami seorang guru juga dapat membangun karakter religius siswa. Diantara karakter religius yang dapat dibangun melalui pembelejaran matematika adalah sikap teliti, hemat dan cermat; jujur, tegas, dan bertanggungjawab; pantang menyerah dan optimis; rendah hati; menjadikan siswa agar senantiasa dekat dengan Allah; menanamkan akhlak terpuji dalam diri siswa; dan sifat ikhlas dalam diri siswa.
\end{abstract}

Kata Kunci:karakter religius, pembelajaran matematika

\section{PENDAHULUAN}

Sejak dahulu hingga saat ini belum ada kesepakatan yang bulat diantara matematikawan tentang apa yang disebut matematika itu. Untuk mendeskripsikan definisi matematika para matematikawan belum pernah mencapai titik "puncak" kesepakatan yang sempurna. Hal ini dikarenakan objek kajian matematika yang sangat luas, sehingga para matematikawan bebas mengungkapkan pendapat mereka masing-masing berdasarkan sudut pandang, kemampuan, pemahaman dan pengalamannya yang mereka alami masing-masing. Penjelasan mengenai apa dan bagaimana matematika itu akan selalu terus mengalami perkembangan seiring pengetahuan, dan kebutuhan manusia serta laju perkembangan zaman. ${ }^{1}$

Istilah matematika berasal dari kata Yunani "mathein" atau "mathenein" yang artinya mempelajari. Kedua kata itu (mathein dan mathenein)erat kaitannya dengan kata Sansekerta

\footnotetext{
1 Abdul Halim Fathani, "Matematika Hakikat \& Logika” (Jogjakarta: Ar-Ruzz Media, 2012), 17.
} 
"medha" atau "widya" yang artinya kepandaian, "ketahuan" atau "intelegensia". ${ }^{2}$ Matematika merupakan ilmu tentang bilangan dan ruang yang mempelajari tentang hubungan pola, bentuk serta struktur. ${ }^{3}$ Oleh sebab itu matematika tidak pernah terlepas dari bilangan dan angka, penuangan kalimat-kalimat pada matematika selalu bermuara pada angka dan bilangan.

Adapun pembelajaran matematika adalah suatu proses pemberian pengalaman belajar kepada siswa melalui serangkaian kegiatan pembelajaran yang telah direncanakan sehingga siswa memperoleh kompetensi mengenai bahan matematika yang dipelajari. ${ }^{4}$ Dalam matematika terkandung nilai-nilai islami, sehingga melalui pembelajaran matematika guru dapat membangun karakter religius siswa.

\section{PEMBAHASAN}

\section{Karakter Religius}

Religius berasal dari kata "religi" yang berasal dari bahasa asing "religion" yang berarti agama atau kepercayaan akan adanya sesuatu kekuatan kodrati di atas manusia. Sedangkan "religius" berasal dari kata "religious" yang artinya adalah sifat religi yang melekat pada diri seseorang. Menurut Suparlan religius adalah sikap dan perilaku yang patuh dalam melaksanakan ajaran agama yang dianut oleh setiap individu, toleran terhadap pelaksanaan ibadah agama lain, serta senantiasa hidup rukun dengan pemeluk agama lain. Karakter religius sangatlah dibutuhkan oleh siswa dalam menghadapi perubahan zaman dan degradasi moral, siswa diharapkan mampu memiliki dan berperilaku dengan ukuran baik dan buruk sesuai dengan ketentuan dan ketetapan agama. $^{5}$

Agama merupakan ajaran yang mendasar yang menjadi pandangan atau pedoman hidup bagi pemeluknya. Pengertian dari pandangan hidup adalah "konsep nilai yang dimiliki seseorang atau sekelompok orang mengenai suatu kehidupan". Adapun yang dimaksud nilai-nilai adalah sesuatu yang dipandang berharga dalam kehidupan manusia serta mempengaruhi sikap hidupnya.

Pandangan hidup (ways of life) merupakan suatu hal yang penting dan hakiki bagi setiap individu, karena dengan adanya pandangan hidup mereka memiliki pedoman yang jelas untuk menjalani kehidupan di dunia ini. pandangan hidup setiap orang berbeda-beda, sebagai contoh dalam hal agama, tidak semua umat manusia mempunyai agama yang sama, ada yang islam, kristen, hindu, budha dan lain-lain.

Pandangan hidup mengandung tiga nilai yaitu nilai-nilai yang bersumber pada agama, ideologi dan filsafat. Agama berperan sebagai suatu sistem keyakinan yang mendasar, sakral, dan menyeluruh mengenai hakikat kehidupan yang pusatnya ialah keyakinan terhadap Tuhan.

\footnotetext{
${ }^{2}$ Hardi Suyitno, "Pengenalan Filsafat Matematika" (Semarang: Fakultas Matematika dan Ilmu Pengetahuan Alam Universitas Negeri Semarang, 2014), 12.

${ }^{3}$ Erman Suherman, “Strategi Pembelajaran Matematika Kontemporer” (Bandung: JICA-UPI, 2003), 19.

${ }^{4}$ Cecep Kustandi, "Media Pembelajaran: Manual Dan Digital” (Bogor: Ghalia Indonesia, 2011), 5.

5 ELearning Pendidikan, "Membangun Karakter Religius Pada Siswa Sekolah Dasar,” 2011, http://www.elearningpendidikan.com.
} 
Sedangkan ideologi berperan sebagai suatu sistem paham yang ingin menjelaskan dan melakukan perubahan dalam suatu kehidupan terutama dalam aspek sosial-politik. Adapun filsafat berperan sebagai sistem berpikir yang radikal, spekulatif, dan induk dari pengetahuan.

Pandangan hidup manusia dapat diwujudkan dalam bentuk cita-cita, sikap hidup, keyakinan hidup, dan yang lebih konkrit lagi adalah perilaku dan tindakan. Pandangan hidup manusia akan mengarah kepada orientasi hidup seseorang dalam menjalani kehidupan di dunia ini. Bagi seorang muslim misalnya, hidup itu berasal dari Allah Yang Maha Segala-galanya yang menciptakan kehidupan serta kebinasaan, kehidupan tidak hanya sekedar di dunia, akan tetapi juga kehidupan yang kekal yaitu kehidupan di akhirat kelak. Pandangan hidup seorang muslim berlandaskan ajaran tauhid dimana ajaran tersebut bersumber pada al-Qur'an dan Sunnah Nabi yang menjadi teladan bagi setiap umat muslim.

Agama memiliki posisi dan peranan yang sangat penting bagi umat manusia dalam menjalani kehidupan di dunia. Agama dapat berfungsi sebagai faktor motivasi, profetik, kritik , kreatif, intergratif, sublimatif dan liberatif.

Karena agama begitu mendasar dalam kehidupan dan mempunyai fungsi yang sangat penting dalam kehidupan manusia maka agama dapat dijadikan sebagai nilai dasar bagi pendidikan, termasuk pendidikan karakter, sehingga melahirkan model pendekatan pendidikan berbasis agama. Pendidikan karakter yang berbasis pada agama merupakan pendidikan yang mengembangkan nilainilai berdasarkan agama yang membentuk pribadi, sikap, dan tingkah laku yang utama atau luhur dalam kehidupan. Dalam agama islam, pendidikan karakter memiliki suatu kesamaan dengan pendidikan akhlaq.

Dalam agama Islam ajaran tentang akhlak mempunyai peranan yang sangat penting sebagaimana ajaran tentang aqidah, ibadah, dan muamalah. Bahkan Nabi akhiru zaman yaitu Nabi Muhammad saw diutus oleh Allah untuk menyempurnakan akhlak manusia, "innamaa buitstu liutannima makaarim al-akhlak". Menyempurnakan aklak manusia berarti mengikis akhlak yang buruk agar hilang serta diganti oleh akhlak yang mulia dan meningkatkan akhlak yang sudah baik menjadi lebih baik lagi daripada sebelumnya. Itulah kemuliaan hidup manusia sebagai makhluk Allah yang paling utama dan paling sempurna. Dapat kita tarik kesimpulan bahwa membangun akhlaq sangatlah penting sehingga melekat dengan kerisalahan Nabi. ${ }^{6}$

Menurut Zayadi, sumber nilai yang berlaku dalam kehidupan manusia digolongkan menjadi dua macam yaitu: (1) Nilai ilahiyah yaitu nilai yang berhubungan dengan ketuhanan atau habul minallah, dimana inti dari ketuhanan adalah keagamaan yang tercermin dalam iman, islam, ihsan, taqwa, ikhlas, tawakkal, syukur, dan sabar, (2) Nilai Insaniyah yaitu nilai yang berhubungan

\footnotetext{
${ }^{6}$ Hadedar Nashir, "Pendidikan Karakter Berbasis Agama Dan Budaya" (Yogyakarta: Multi Presindo, 2017), $22-24$.
} 
dengan sesama manusia atau habul minanas yang berisi budi pekerti yang meliputi silaturahim, alukhuwah, al musawah, al-adalah, Husnu Dzan, tawadlu, al-wafa, insyirah dan amanah. ${ }^{7}$

\section{Pembelajaran Matematika}

Istilah matematika berasal dari kata Yunani "mathein" atau "mathenein" yang artinya mempelajari. Kedua kata itu (mathein dan mathenein)erat kaitannya dengan kata Sansekerta "medha" atau "widya" yang artinya kepandaian, "ketahuan" atau "intelegensia".

Adapun pengertian pembelajaran menurut Cecep Kustandi dan Bambang Sucipto adalah usaha sadar seorang guru untuk membantu siswa agar mereka dapat belajar sesuai dengan kebutuhan dan miat mereka. ${ }^{9}$ Sedangkan pembelajaran matematika adalah suatu proses pemberian pengalaman belajar kepada siswa melalui serangkaian kegiatan pembelajaran yang telah direncanakan sehingga siswa memperoleh kompetensi mengenai bahan matematika yang dipelajari. ${ }^{10}$

Jadi dapat disimpulkan bahwa pembelajaran matematika adalah usaha seorang guru untuk membantu siswanya agar belajar sesuai dengan kebutuhan serta minat mereka masing-masing.

\section{Membangun Sikap Teliti, Hemat dan Cermat Melalui Pembelajaran Matematika}

Matematika disebut juga dengan ilmu hitung karena seperti yang kita ketahui bahwa matematika banyak yang berkaitan dengan kegiatan hitung-menghitung. ${ }^{11}$ Kegiatan hitung menghitung dalam matematika dapat kita temui mulai dari tingkat dasar hingga tingkat perguruan.

Matematika disebut juga dengan ilmu hitung karena pada hakikatnya matematika mempunyai hubungan yang erat dengan hitung menghitung. Untuk memperoleh hasil yang tepat dalam menggunakan operasi hitung pada matematika sangat diperlukan kecermatan serta ketelitian, dan yang sedang populer adalah cara berhemat dan cepat akan tetapi juga tepat.

Kita dituntut untuk teliti dan cermat dalam mengerjakan soal matematika, mulai dari cara mengerjakan hingga mendapatkan hasil haruslah sesuai dengan langkah-langkah pengerjaannya. Dan setelah kita memperoleh jawaban, maka harus kita cek kembali apakah jawaban kita sudah sesuai dengan permasalahan ataukah belum.

Selain itu, matematika juga melatih kita untuk bersikap hemat dan tidak boros. Kita dapat melihat bahwa kebanyakan dari orang matematika selalu simpel, baik dalam hal bertindak maupun berbicara, selalu to te point, tidak bertele-tele seperti halnya orang sosial. Kalimat yang digunakanpun ringkas dan mudah untuk dipahami. ${ }^{12}$

\footnotetext{
7 Zayadi, “Desain Pendikan Karakter” (Jakarta: Kencana Gramedia Grup, 2011), 73.

${ }^{8}$ Suyitno, "Pengenalan Filsafat Matematika."

${ }^{9}$ Kustandi, "Media Pembelajaran: Manual Dan Digital."

${ }^{10}$ Kasmad Rifangi, "Pembelajaran Matematika Kelas IV Di Madrasah Ibtida'iyah Ma'arif Sendang Karangsari Pengasin Kulon Progo Yogyakarta," in Skripsi PGMI Fakultas Ilmu Tarbiyah Dan Keguruan UIN Sunan Kalijajaga, 2010, 12.

${ }^{11}$ Halim Fathani, "Matematika Hakikat \& Logika."

12 Ibid.
} 
Dan yang membedakan lagi, apabila terdapat suatu masalah matematika, yang menjadi fokus utama bukanlah solusi yang tepat, akan tetapi yang lebih diutamakan adalah metode untuk mencari solusi tersebut. Metode yang digunakan haruslah cepat dan tepat. Sehingga kita dapat memperoleh hasil yang efektif dan efisien.

Berikut ini akan disajikan contoh soal.

Tentukan hasil dari $116 \times 84$.

Seseorang mungkin akan menjawab dengan cara berikut ini.

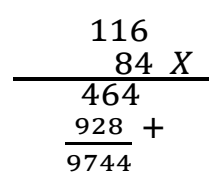

Tetapi mungkin seseorang juga kan menjawab sebagai berikut.

$116 \times 84=10000-256$

Diperoleh dari $(a+b)(a-b)=a^{2}-b^{2}$

Sehingga:

$116=(100+16)$

$84=(100-16)$

Jadi, $116 \times 84=(100+16) \times(100-16)=100^{2}-16^{2}=10000-256=9744$

Dari sini dapat kita tarik kesimpulan yaitu matematika mengajarkan kita cara untuk berhemat. Sebagai analogi, definisi dalam matematika adalah jalan kaki, maka teorema pertama ibarat sepeda motor, teorema kedua ibarat mobil, dan teorema yang ketiga ibarat pesawat. Menyelesaikan matematika dengan definisi dapat diibaratkan bagai menempuh perjalanan dengan jalan kaki. Menyelesaikan matematika dengan teorema dapat diibaratkan menempuh perjalanan yang jauh dengan kendaraan. Cara pertama diibaratkan dengan jalan kakii, sedangkan cara yang kedua diibaratkan dnegan kendaraan. ${ }^{13}$

\section{Membangun Sikap Jujur, Tegas dan Bertanggungjawab Melalui Pembelajaran Matematika}

Kita mengetahui bahwa matematika merupakan ilmu pasti. Apabila kita menjawab jawaban dengan salah, maka sudah pasti salah. Dan sebaliknya apabila kita menjawab pertanyaan dengan benar, maka juga akan benar. Di dalam matematika hanya ada satu jawaban, benar atau salah, tidak ada jawaban yang benar sekaligus salah atau abu-abu.

Jadi ketika kita menjawab soal perkalian bilangan bulat $4 \times 6$ maka haruslah dijawab secara tegas, sehingga tidak ada keraguan sedikitpun. Selain itu kita haruslah jujur dalam menjawabnya, sebab jika kita tidak jujur, kita tidak akan pernah tau mengenai bagaimana prosesnya. Dan hal tersebut akan berdampak ketika kita menjawab soal lain yang hampir sama dan kita tidak akan bisa menjawab nantinya.

${ }^{13}$ Ibid., hlm. 101 
Selain itu untuk membangun sikap jujur siswa dapat dilakukan analogi terhadap perkalian bilangan bulat yaitu:

(1) positif $x$ positif $=$ positif

(2) positif $x$ negatif $=$ negatif

(3) negatif $x$ positif $=$ negatif

(4) negatif $x$ negatif $=$ positif

Apabila dikembangkan ke dalam kesimpulan analogi adalah sebagai berikut: ${ }^{14}$

(1) benar jika dikatakan benar maka perilaku tersebut adalah benar

(2) benar jika dikatakan salah maka perilaku tersebut adalah salah

(3) salah jika dikatakan benar maka perilaku tersebut adalah salah

(4) salah jika dikatakan salah maka perilaku tersebut adalah benar

Dengan demikian dapat ditarik kesimpulan bahwa kita harus selalu bersikap dan berperilaku jujur. Tidak ada yang baik dari suatu kebohongan.

\section{Membangun Sikap Pantang Menyerah dan Optimis Melalui Pembelajaran Matematika}

Sikap pantang menyerah dan optimis merupakan suatu cerminan ketika kita menemui suatu kegagalan dalam melakukan pemrosesan jawaban. Sikap pantang menyerah berarti kita terus berusaha walaupun mengalami kegagalan. Arti gagal disini berarti jawaban yang diperoleh belum sesuai. Sehingga kita akan selalu terus berusaha menemukannya jawabannya hingga ketemu.

Adapun sikap optimis merupakan sifat percaya diri untuk dapat menyelesaikan semua prosesnya. Sikap optimis menimbulkan keyakinan kuat dalam melalui segala sesuatu yang menghambatnya sampai kita menemukan apa yang kita cita-citakan.

\section{Membangun Sikap Rendah Hati Melalui Pembelajaran Matematika}

Pada penulisan himpunan bilangan bulat $\mathrm{Z}=\{\ldots,-3,-2,-1,0,1,2,3, \ldots$.$\} ada pertanyaan$ yang dapat ditulis. Mengapa tidak ditulis saja $Z=\{\ldots .,-3 .-2,-1,0,+1,+2,+3, \ldots$.$\} . Makna yang$ dapat kita ambil dari bilangan +3 cukup ditulis 3 dan seterusnya yaitu bahwa kepositifan diri sendiri tidak perlu kita tonjol-tonjolkan kepada orang lain. Sebaliknya kita tidak menulis -3 dengan 3, hal ini berarti kenegatifan diri sendiri itu haruslah kita ingat-ingat untuk menghadirkan rasa penyesalan dan taubat. ${ }^{15}$ Hal ini berdasarkan hadits Nabi Muhammad saw bahwa tanda-tanda kebahagiaan ada 2 yaitu: (1) senatiasa mengingat keburukan (kenegatifan), dan (2) senantiasa melupakan kebaikan (kepositifan) yang pernah kita lakukan. Sebaliknya tanda-tanda kesengsaraan

\footnotetext{
${ }^{14}$ Abdussakir, "Matematika I: Kajian Integratif Matematika Dan Al-Qur'an" (Malang: UIN Maliki Press, 2009).

${ }^{15}$ Abdussakir, "Internaslisasi Nilai-Nilai Islami Dalam Pembelajaran Matematika Dengan Strategi Analogi," 2017.
} 
itu juga ada 2 yaitu: (1) senatiasa melupakan keburukan yang kita lakukan dan (2) senantiasa mengingat kebaikan (kepositifan) yang pernah kita lakukan. ${ }^{16}$

Dari uraian diatas dapat kita tarik kesimpulan bahwa kepositifan yang ada pada diri kita tidak perlu kita tonjolkan kepada orang lain, dan kenegativan yang ada pada diri kita haruslah kita ingat. Hal ini bertujuan agar kita tidak menjadi orang yang sombong dengan mengandalkan kepositifan pada diri kita, serta menjadikan kita senantiasa menghadirkan rasa penyesalan dan selalu bertaubat kepada Allah swt.

\section{Membangun Pribadi Muslim yang Senantiasa Dekat dengan Allah}

Cara membangun pribadi muslim yang senatiasa dekat dengan Allah melalui pembelajaran matematika adalah dengan mengenalkan analogi bilangan asli dan bilangan prima. Telah kita ketahui bahwa dalam matematika terdapat enam himpunan bilangan yaitu himpunan bilangan asli, himpunan bilangan cacah, himpunan bilangan bulat, himpunan bilangan rasional, himpunan bilangan real, dan himpunan bilangan kompleks.

Himpunan bilangan asli dinotasikan dengan huruf $\mathbf{N}$ yang diambil dari kata Natural Numbers. Himpunan asli adalah sebagai berikut:

$$
\mathbb{N}:=\{1,2,3, \ldots\}
$$

Adapun himpunan bilangan cacah dinotasikan dengan huruf $\mathrm{W}$ yang diambil dari kata Whole Numbers. Himpunan bilangan cacah adalah sebagai berikut:

$$
\mathrm{W}=\{0,1,2,3,4,5, \ldots .\}
$$

Terlihat bahwa himpunan bilangan cacah adalah gabungan dari himpunan bilangan asli dan $\{0\}$.

Adapun himpunan bilangan bulat dinotasikan dengan huruf $\mathrm{Z}$ yaitu:

$$
Z=\{\ldots .,-4,-3,-2,-1,0,1,2,3,4,5, \ldots\}
$$

Terlihat bahwa himpunan bilangan bulat memuat himpunan bilangan cacah dan juga bilangan asli.

Adapun himpunan bilangan rasional dinotasikan dengan huruf $\mathbf{Q}$ adalah sebagai berikut:

$$
\mathbb{Q}:=\left\{\frac{p}{q}: p, q \in \mathbb{Z}, q \neq 0\right\}
$$

Himpunan bilangan rasional memuat semua anggota bilangan bulat.

Sedangkan himpunan bilangan real dinotasikan dengan huruf $\mathrm{R}$ yaitu memuat semua bilangan yaitu bilangan rasional dan irrasional.

Dan himpunan bilangan kompleks dinotasikan dengan huruf $\mathrm{C}$ adalah sebagai berikut:

$\mathrm{C}=\left\{a+b i: a, b \hat{\mathrm{I} \mathrm{R}}, i^{2}=-1\right\}$.

Karena semua bilangan real $a$ dapat ditulis sebagai $a+0 i$, maka himpunan bilangan kompleks memuat semua bilangan real. Jadi:

$$
\mathbb{N} \subset \mathbb{W} \subset \mathbb{Z} \subset \mathbb{Q} \subset \mathbb{R} \subset \mathbb{C}
$$

\footnotetext{
${ }^{16}$ Muhammad Nawawi, "Nahaihul 'Ibad” (Surabaya: Daar an-Nasyr al-Misyiriyah, 1994), 24.
} 
Sebenarnya semua bilangan sudah ada dan disediakan oleh sang pencipta yaitu Allah swt. Manusia sebagai makhluk Allah hanya menemukannya dan secara kebetulan manusia menemukan dimulai dari himpunan bilangan yang paling sederhana, yaitu bilangan asli.

Jika dilakukan perumpamaan atau analogi kasar, misalkan bahwa himpunan bilangan kompleks mewakili semua manusia yang penuh dengan aneka sifat, yaitu jelas (real) dan tidak jelas (imajiner), baik dan buruk, serta positif dan negatif, yang penuis menyebutkan sebagai manusia kompleks. Setelah itu dilakukan seleksi-seleksi yang ketat sehingga menghasilkan manusia yang jelas (tidak imajiner), tetapi masih bersifat baik dan buruk, positif dan negatif, serta yang rasional dan irasional, yang dikenal dengan manusia real. Kemudian dilakukan lagi seleksi lebih lanjut, dengan membuang manusia yang tidak rasional sehingga diperoleh manusia rasional, akan tetapi terkadang masih bersifat baik dan buruk, positif dan negatif, serta manusia utuh (bulat) dan tidak utuh (pecahan). Kemudian dilakukan seleksi lebih lanjut dengan membuang manusia yang tidak utuh (pecahan) sehingga diperoleh manusia utuh (bulat), akan tetapi masih memiliki sifat positif, nol dan negatif. Kemudian dilakukan seleksi lagi dengan membuang manusia yang negatif, sehingga terbentuklah manusia cacah, tetapi masih bersifat sia-sia (nol) dan positif. Selanjutnya dilakukan seleksi dengan membuang manusia yang sia-sia (yang mengerjakan sesuatu yang tidak bermakna tetapi bukan kejelekan), sehingga pada akhirnya diperolehlah manusia asli.

Dengan analogi tersebut, kita dapat meyimpulkan bahwa manusia asli, natural, atau mungkin fitrah mempunyai ciri-ciri sebagai berikut: (a) Merupakan manusia biasa (tetap manusia kompleks); (b) Merupakan manusia yang jelas, tidak imajiner; (c) Merupakan manusia yang rasional, bukan yang irrasional; (d) Merupakan manusia yang utuh (bulat), bukan yang pecahan; (e) Merupakan manusia yang tidak sia-sia atau nol serta tidak melakukan hal yang sia, bukan yang nol; (f) Merupakan manusia yang bersifat positif serta gemar melakukan hal yang positif, bukan melakukan hal yang negatif.

Dalam konteks himpunan bilangan asli inilah, maka muncul suatu konsep bilangan prima yang didefinisikan sebagai berikut. Jika $\mathrm{p}$ adalah bilangan bulat positif (bilangan asli) lebih dari satu yang hanya mempunyai pembagi positif 1 dan $\mathrm{p}$ sendiri, maka $\mathrm{p}$ disebut dengan bilangan prima. ${ }^{17}$

Adapun contoh bilangan prima adalah sebagai berikut:

$2,3,5,7,11,13,17,19,23,31,37$, dan 43 .

Selain bilangan prima, kita juga mengenal istilah bilangan komposit, jika suatu bilangan mempunyai pembagi selain 1 dan bilangan itu sendiri, maka disebut bilangan komposit. Contoh bilangan komposit adalah sebagai berikut:

$4,6,8,9,10,12,14,15$, dan 16.

${ }^{17}$ Gatot Muhsehto, “Dasar-Dasar Teori Bilangan” (Jakarta: PGSM, 1997), 92. 
Bilangan komposit dapat berupa bilangan genap ataupun bilangan ganjil. Bilangan 1 hanya mempunyai satu pembagi, yaitu dirinya sendiri, maka 1 bukanlah bilangan bilangan prima dan juga bukan bilangan komposit.

Berdasarkan penjelasan diatas, maka dapat kita simpulkan bahwa himpunan bilangan asli terbagi menjadi tiga kelompok, yaitu 1, bilangan prima, dan bilangan komposit. Jika diadakan suatu analogi dengan bilangan prima, maka akan diperoleh manusia prima. Manusia prima adalah manusia yang senantiasa dekat dengan yang satu, yang esa, dzat yang maha tunggal, dzat yang tiada duanya yaitu Allah SWT. ${ }^{18}$

Telah kita ketahui bahwa Allah swt adalah satu, esa, atau tunggal, sebagaimana disebutkan dalam firman Allah swt QS. Al-Ikhas ayat 1:

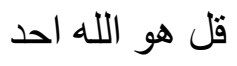

Artinya: Katakanlah: "Dia-lah Allah, yang Maha Esa".

Definisi dari manusia prima adalah manusia yang tidak ada penghalang (hijab) antara dirinya dengan Dzat Yang Maha Esa yaitu Allah swt. Hati mereka (manusia prima) selalu terpaut dengan Allah swt. Tidak ada penyakit dalam hati mereka yang dapat menghalangi hubungannya dengan Allah swt. Hatinya akan selalu bergetar dengan dzikrullah.

Faktor dari bilangan prima adalah 1 dan bilangan itu sendiri. Bilangan prima pada hakikatnya tersusun dari bilangan 1, dan sebenarnya semua bilangan (prima atau komposit) tersusun dari 1. Karena bilangan prima dekat dengan 1, maka bilangan prima akan mampu merasakan bahwa dirinya sendiri tersusun dari bilangan 1. Analogi dari hal ini adalah bahwa manusia prima akan merasa bahwa dirinya tidak mampu berbuat apa-apa tanpa adanya yang mengatur dan tanpa adanya kehendak Allah swt. Semua kehendaknya adalah kehendak Allah. Semua tindakannya tercipta karena kehendak Allah swt. Hanya manusia prima yang mampu merasakan ini.

Bilangan prima pada dasarnya juga merupakan bilangan asli, sehingga sifat-sifat bilangan asli juga berlaku untuk bilangan prima. Jadi, manusia prima adalah manusia asli dengan sifat-sifat yang khusus, yaitu selalu dekat dengan yang Maha Esa yaitu Allah swt dan juga merasa bahwa keberadaan dan perilakunya atas kehendak Allah swt.

Berdasarkan uraian diatas dapat disimpulkan bahwa manusia prima adalah: (a) manusia biasa (tetap manusia kompleks); (c) manusia yang jelas, tidak imajiner; (d) manusia yang rasional, bukan yang irrasional (e) manusia yang utuh (bulat), bukan yang pecahan; (f) manusia yang tidak sia-sia serta tidak melakukan hal yang sia, bukan yang nol; (g) manusia yang bersifat positif dan

\footnotetext{
${ }^{18}$ Saiful Hadi, “Tinjauan Matematis Manusia Prima,” Ta'allum 1 (2013): 240.
} 
gemar melakukan hal yang positif, bukan yang negatif; (h) manusia yang dekat dengan Yang Esa, (i) manusia yang sadar bahwa dirinya tidak ada apa-apanya selain karena kehedak Allah swt. ${ }^{19}$

Dengan analogi tersebut kita dapat memperoleh gambaran tentang manusia prima ditinjau dari matematis. Maka hendaknya dalam pembelajaran analogi tersebut disampaikan kepada muridnya agar mereka mengetahui bagaimana cara membentuk manusia yang selalu dekat dengan Yang Esa atau biasa disebut dengan manusia prima.

\section{Menanamkan Akhlak Terpuji Siswa melalui Pembelajaran Matematika pada Materi Operasi Bilangan Bulat}

Mari kita perhatikan contoh dibawah ini.

a. $8+7=15$, positif 8 apabila ditambah dengan positif 7 menghasilkan bilangan positif yang lebih dari 8.

b. $8+(-7)=1$, positif 8 apabila ditambah dengan negatif 7 menghasilkan bilangan yang kurang dari 8.

c. $-8+7=-1$, negatif 8 apabila ditambah dengan positif 7 menghasilkan bilangan yang lebih dari -8 .

d. $-8+(-7)=-15$, negatif 8 apabila ditambah dengan negatif 7 menghasilkan bilangan yang kurang dari -8 .

Adapun kesimpulan analogi tersebut adalah sebagai berikut:

a. Kebaikan yang ditambah dengan kebaikan kita lakukan akan menghasilkan nilai kebaikan yang lebih besar dari kebaikan semula.

b. Kebaikan yang diikuti dengan keburukan akan mengurangi nilai kebaikan yang pernah kita lakukan.

c. Keburukan yang diikuti dengan kebaikan akan mengurangi nilai keburukan yang pernah kita lakukan.

d. Keburukan apabila ditambah lagi dengan keburukan yang kita lakukag akan menghasilkan nilai keburukan yang lebih besar dari keburukan semula. ${ }^{20}$

Dengan demikian kita sebagai umat manusia hendaknya selalu melakukan kebaikan setelah melakukan kejahatan, ataupun senantiasa melakukan kebaikan tanpa melakukan kejahatan. Pada intinya kebaikan yang kita lakukan mempunyai dampak yang positif bagi diri kita maupun orang lain, namun suatu kejahatan pastilah mempunyai dampak negatif baik bagi diri kita maupun orang lain. Oleh karena itu umat manusia hendaknya senantiasa melakukan kebaikan. Hal ini sesuai dengan hadits Nabi Muhammad saw yang artinya:

\footnotetext{
${ }^{19}$ Ibid.

${ }^{20}$ Abdussakir, "Internaslisasi Nilai-Nilai Islami Dalam Pembelajaran Matematika Dengan Strategi Analogi."
} 
"Dari Abu Dzar, Jundub bin Junadah dan Abu „Abdurrahman, Mu"adz bin Jabal radhiyallahu „,anhuma, dari Rasulullah Shallallahu ,, alaihi wa Sallam, beliau bersabda: “Bertakwalah kepada Allah di mana saja engkau berada dan susullah sesuatu perbuatan dosa dengan kebaikan, pasti akan menghapuskannya dan bergaullah sesama manusia dengan akhlaq yang baik”. [HR. Tirmidzi, ia telah berkata: Hadits ini hasan, pada lafazh lain derajatnya hasan shahih].

\section{Menanamkan Sikap Ikhlas Dalam Diri Siswa Melalui Pembelajaran Matematika}

Menannamkan sikap ikhlas dalam diri siswa dapat kita lakukan dengan menganalogikan pemberian dan harapan melalui pembagian bilangan 1 dengan bilangan bulat positif lainnya. Mari kita perhatikan contoh berikut ini:

$1:$ mendekati tak hingga $=$ mendekati nol

$1: 100=0,01$

$1: 10=0,1$

$1: 1=1$

$1: 0,1=10$

$1: 0,01=100$

$1: 0,000000001=1000000000$

$1:$ mendekati nol = mendekati tak hingga .

Kemudian contoh ini dapat kita analogikan sebagai analogi induktif yang dijelaskan dalam bentuk pembagian : harapan $=$ hasil .

Hal ini dapat diartikan bahwa semakin besar harapan untuk suatu pemberian maka sebenarnya hasilnya makin kecil. Dan sebaliknya, pemberian yang semakin tidak disertai harapan balasan (ikhlas), maka hasilnya semakin menuju tak hingga. ${ }^{21}$

Contoh operasi pembagian ini juga dapat digunakan untuk menjelaskan tingkat rasa syukur seseorang terhadap karunia duniawi yang diberikan oleh Allah swt. Adapun analoginya adalah jika seseorang senantiasa membandingkan dirinya dengan orang yang di atasnya dalam urusan duniawi, maka nilai syukurnya akan semakin berkurang, dan sebaliknya jika seseorang senantiasa membandingkan dirinya dengan orang yang berada di bawahnya dalam urusan duniawi, maka nilai syukurnya akan semakin bertambah.

\section{SIMPULAN}

Religius adalah sikap dan perilaku yang patuh dalam melaksanakan ajaran agama yang dianut oleh setiap individu, toleran terhadap pelaksanaan ibadah agama lain, serta senantiasa hidup rukun dengan pemeluk agama lain. Karakter religius sangatlah dibutuhkan oleh siswa dalam menghadapi perubahan zaman dan degradasi moral, siswa diharapkan mampu memiliki dan berperilaku dengan ukuran baik dan buruk sesuai dengan ketentuan dan ketetapan agama. Salah satu cara membangun karakter religius adalah melalui pembelajaran matematika. Diantara karakter religius yang dapat dibangun melalui pembelejaran matematika adalah sikap teliti, hemat dan cermat; jujur, tegas, dan

21 Ibid. 
bertanggungjawab; pantang menyerah dan optimis; rendah hati; menjadikan siswa agar senantiasa dekat dengan Allah; menanamkan akhlak terpuji dalam diri siswa; dan sifat ikhlas dalam diri siswa.

\section{DAFTAR RUJUKAN}

Abdussakir. "Internaslisasi Nilai-Nilai Islami Dalam Pembelajaran Matematika Dengan Strategi Analogi," 2017.

Abdussakir. "Matematika I: Kajian Integratif Matematika Dan Al-Qur'an.” Malang: UIN Maliki Press, 2009.

ELearning Pendidikan. "Membangun Karakter Religius Pada Siswa Sekolah Dasar,” 2011. http://www.elearningpendidikan.com.

Hadi, Saiful. "Tinjauan Matematis Manusia Prima.” Ta'allum 1 (2013): 240.

Halim Fathani, Abdul. "Matematika Hakikat \& Logika," 17. Jogjakarta: Ar-Ruzz Media, 2012.

Kustandi, Cecep. "Media Pembelajaran: Manual Dan Digital," 5. Bogor: Ghalia Indonesia, 2011.

Muhsehto, Gatot. "Dasar-Dasar Teori Bilangan," 92. Jakarta: PGSM, 1997.

Nashir, Hadedar. "Pendidikan Karakter Berbasis Agama Dan Budaya," 22-24. Yogyakarta: Multi Presindo, 2017.

Nawawi, Muhammad. "Nahaihul 'Ibad," 24. Surabaya: Daar an-Nasyr al-Misyiriyah, 1994.

Rifangi, Kasmad. "Pembelajaran Matematika Kelas IV Di Madrasah Ibtida'iyah Ma'arif Sendang Karangsari Pengasin Kulon Progo Yogyakarta." In Skripsi PGMI Fakultas Ilmu Tarbiyah Dan Keguruan UIN Sunan Kalijajaga, 12, 2010.

Suherman, Erman. "Strategi Pembelajaran Matematika Kontemporer," 19. Bandung: JICA-UPI, 2003.

Suyitno, Hardi. "Pengenalan Filsafat Matematika," 12. Semarang: Fakultas Matematika dan Ilmu Pengetahuan Alam Universitas Negeri Semarang, 2014.

Zayadi. "Desain Pendikan Karakter," 73. Jakarta: Kencana Gramedia Grup, 2011. 